Мыкынова К. Б. ${ }^{1}$, Янгибаева Ж. Т. ${ }^{1}$

И. Арабаев атындагы Көркөм сүрөт жана дизайн кафедрасынын магистранты, Кыргызстан

Мыкынова К. Б. ${ }^{1}$, Янгибаева Ж. Т. ${ }^{1}$

1 магистрант кафедры ИЗО и дизайна КГУ им. И.Арабаева, Кыргызстан

Mykynova K. B. ${ }^{1}$, Iangibaeva Z. T. ${ }^{1}$

1 master's student of the Department of fine ARTS and design KSU. I. Arabaev, Kyrgyzstan

КИЙИЗ КӨРКӨМ ӨНӨРУ БОЮНЧА САБАКТЫ ӨНУКТУРУУ ӨЗГӨЧӨЛУКТӨРУ

СОВЕРШЕНСТВОВАНИЕ ПРОЦЕССА ЗАНЯТИЙ

ПО ХУДОЖЕСТВЕННОЙ ОБРАБОТКЕ ВОЙЛОКА

\title{
IMPROVING THE PROCESS OF TRAINING FOR ARTISTIC PROCESSING OF FELT
}

Аннотация: Макалада кийизден жасалган көркөм өнөр боюнча сабакты өнүктүрүү өзгөчөлүктөрүнө арналган. Бул этникалык элементин ишке ашыруу жана сактоо жөнүндө маселени карайт. Макала окуучуларга жана көркөм өнөр мектептеринде, өздүк көркөм чыгармачылык студенттери үчүн жазылган.

Аннотация: Статья посвящена особенностям и совершенствованию процесса занятий художественной обработки войлока. Затрагивается проблема реализации и сохранения этнического элемента. Пособие адресовано школьникам и студентам художественных учебных заведений, любителям декоративно-прикладного искусства.

Annotation: The article is devoted to the peculiarities and improvement of the process of practicing artistic processing of felt. The problem of the realization and preservation of the ethnic element is touched upon. The manual is addressed to schoolchildren and students of art schools, lovers of decorative and applied arts.

Негизги сөздөр: көркөм кийиз; көркөм өнөр; эстетикалык билим берүү; кийиз жасоо; кыргыз элинин салты.

Ключевые слова: художественный войлок; искусство; эстетическое воспитание; войлоковаляние; традиции кыргызов.

Key words: artistic felt; art; aesthetic education; felting; kyrgyz traditions.

Народное искусство является основой формирования духовного мира и интеллектуального опыта подрастающего поколения. Народное искусство есть синтезирующий результат многовекового опыта народа, который отражает его мудрость и талант.

Декоративно-прикладное искусство (в частности войлоковаляние) по своей природе имеет воспитывающий характер: любовь к Родине к своему народу, преклонение перед опытом коллективного познания мира. Глубокий гуманизм народного искусства связывает человека как с обществом, так и с природой, способствует развитию в человеке образности мышления, фантазии, музыкальности, поэтичности, глубокому пониманию красоты мира. 
Сохранение и развитие кыргызского народного искусства у нас всегда рассматривалось не только как важная народно-хозяйственная задача, но и как идеологическая проблема, имеющая непосредственное отношение к формированию национальных художественных культур. Народное искусство во всех своих формах всегда выражает народное понимание жизни, природы, мира. Оно воспевает лучшие черты народного характера: гуманизм, честность, преданность долгу Родине, оптимизм, смелость.

В этом смысле народное и декоративно-прикладное искусство кыргызского народа, являясь частью мировой культуры, не является исключением. Многообразие народного искусства настолько неисчерпаема, что и сегодня оно остаётся малоизученным и невостребованным, в нём много белых пятен, что делает нашу работу вполне актуальной.(3)

Искусство войлока наряду с другими видами искусства формирует художественноэстетический вкус к труду. Каждое новое поколение мастериц вносит новые элементы в форму и содержание данного искусства, как бы «адаптируя» традиционность к современным условиям. (2)

После приобретения независимости Кыргызской Республики появилась возможность для всестороннего изучения всех областей (отраслей) народного искусства, в том числе и искусства войлоковаляния.

Одним из ярчайших образцов народного искусства, которое одновременно носит и трудовой, и воспитательный характер, является войлоковаляние. В народном искусстве традиции валяния у кыргызов были связаны с природой, которая давала для этого - шерсть. Эти материалы часто использовались, и отличались вдохновленным дизайном природы. Большинство мотивов отражают горы, реки, растения, и животные.

Шырдак-культовые войлочные ковры, их орнаменты представляют собой стилизованные абстрактные изображения овец, козлов, собак и т.д.

При изготовлении шырдака два войлочных ковра разных цветов выкладывают друг на друга, затем острым ножом в них прорезают симметричный орнамент и сшивают ковры в один. Ценятся они дороже которых сделаны на станке. Срок его эксплуатации 8-10лет. Шырдаки вешают на стены или застилают ими пол.

Ала кийиз - еще одна разновидность войлочных ковров, напоминающий шырдак, но процесс изготовления совсем другой. Маленькие лоскутки войлока, наложенных друг на друга пропитывают теплой водой, и сворачивают, чтобы соединить слои. В результате получается полотно без четких границ, которые перетекают одна в другую, создавая красочные и сложные рисунки.

Чий - травянистое растение, встречающееся в степи, из сухих стеблей которого плетутся циновки. Они могут быть обычными или с какими-нибудь узорами. Чий часто используются в юртах как дополнительная изоляция или укладывается под ковры для защиты от сырости. Эти маты также играют важную роль в процессе валяния при изготовлении ширдаков и ала-кийиз.

Кыргызские мастера при изготовлении той или иной вещи уделяют большое внимание не только ее прочности, но и художественному оформлению. Художественный вкус находит наиболее яркое выражение в ткачестве, плетении, красочной орнаментике войлочных изделий , вышивке, ювелирном производстве, обработка кожи, дерева. Многие вещи являются подлинными произведениями искусства. Можно сказать, что специфику большинства народных изделий создает орнамент, его размещение и цветовое соотношение. При этом декоративные качества вещей всегда неразрывно связаны с их практическим назначением в быту. Поэтому большинство предметов быта могут быть правильно восприняты только лишь в единстве их художественных и технических сторон. 
Наибольшее сходство, а в некоторых случаях и тождество, форме ремесла и его продукции наблюдается у кыргызов с казахами. Это отмечают многие исследователи. Несмотря на наличие сходных черт в ремесленном производстве у кыргызов, узбеков и таджиков, существует много и принципиально глубоких различий, говорящих о разных истоках. Сходство является следствием заимствования в более позднее время, с тех пор как кыргызы очутились в окружении более сильных в экономическом отношении оседлых народов. Домашнее ремесло последних давно переросло в кустарное производство, развивающиеся в городских условиях и достигшее большого товарного производства.

Анализируя домашнее производства, ремесла, художественные занятия кыргызов, мы пытаемся выяснить характер, степень развития каждого их вида, специфику народного искусства, особенность кыргызского орнамента. (4)

Традиции войлоковаляния исторически обусловлены как материальной, так и духовной культурой народа. Как педагогический феномен они имеют воспитательный и обучающий потенциал (воспитание терпения, творческого отношения к труду и воображения, чувства красоты, развитие мелкой моторики рук, элементарных математических навыков).

Совершенствование процесса занятий по художественной обработке войлока при следующих педагогических условиях:

- выявление воспитательного и обучающего потенциала традиций народных ремесел, в частности, войлоковаляния и формирование у студентов интереса к кыргызскому народному искусству;

- обеспечение профессионально-педагогической направленности процесса изучения чувашского народного ткачества на основе соединения традиционных методов ткачества и новых технологий, формирование у студента позиции «учитель - носитель национальной культуры»;

- разработка и внедрение в учебно-воспитательный процесс педвуза модели системы подготовки учителя технологии к использованию традиций чувашского народного ткачества в профессиональной деятельности.

Изучение декоративно-прикладного искусства, истории его развития, народной культуры и быта необходимо рассматривать не только как деятельность, направленную на изучение искусства родного края, но и как одно из условий, обеспечивающих развитие художественно-творческих способностей на конкретном жизненном материале.

Использование народного, художественного творчества в обучении и воспитании имеет свои истоки, свою историю становления и развития под влиянием отечественной педагогической и эстетической мысли, передового опыта художественного образования и эстетического воспитания, осуществляемого в школе дореволюционного и последующего времени.

Условность, красочность, наглядно-образная специфика языка народного декоративно-прикладного искусства, богатейшая историко-культурная значимость обусловливают его использование в целенаправленном развитии творческих способностей. Творческие способности, направленные на гармоничное развитие теоретического мышления и практических навыков в овладении техниками и приемами создания произведений народного искусства, востребованы во многих видах продуктивной учебной и самостоятельной деятельности учащихся. Активное преобразование окружающего мира в любом виде деятельности является важнейшим условием комплексного и разностороннего развития личности, обеспечивает наиболее эффективные пути познания мира и самоопределения человека и характеризует рост культурного потенциала общества. 


\section{Список использованной литературы:}

1. Богоявленская Д. О путях к творчеству. Наука и жизнь. 1977. №2. 22с.

2. Домашние производства, ремесла, художественные занятия кыргызов//статья. - 2015г. [Электронный ресурс] - Режим доступа. - https://www.open.kg/about-kyrgyzstan/art/arts-andcrafts/2447-domashnie-proizvodstva-remesla-hudozhestvennye-zanyatiya-kyrgyzov.html

3. Кривцун О. А. Психология искусства: [учеб. пособие]. - М.: Высшая школа, 2009. - 446 с.

4. Трофимов А.А. Проблемы народного искусства Чувашии. Чебоксары: Чуваш, кн. изд-во, 1985. - $112 \mathrm{c}$.

\section{References:}

1. Epiphany On ways to be creative. Science and life. 1977. No. 2. 22C.

2. Home production, crafts, art classes of the Kyrgyz//article. - 2015. [Electronic resource] - access Mode. - - https://www.open.kg/about-kyrgyzstan/art/arts-and-crafts/2447-domashnieproizvodstva-remesla-hudozhestvennye-zanyatiya-kyrgyzov.html

3. Krivtsun O. A. Psychology of art: [studies. benefit.] - Moscow: Higher school, 2009. - 446 p.

4. Trofimov A. A. the problem of folk art Chuvashia. Cheboksary: Chuvash, kN. ed., 1985. - 112 p.

Рецензент: к.филол.н., доцент Арзыматова Ч.Ж. 